\title{
Tourism advertising and cyberspaces of travelling
}

\author{
Ana Crăciunescu* \\ Faculty of Letters and Communication Sciences, "Ștefan cel Mare" University, Str. Universității 13, 720229 Suceava, Romania
}

\section{Article info}

History:

Received December 30, 2016

Accepted January 19, 2017

Published March 23, 2017

Key words:

tourism advertising

space

place/non-place

cyberspace

\begin{abstract}
In the context of cyber-globalization, notions such as 'space' and 'place' are reconsidered from anthropologic and consumerist studies points of view. We aim at describing space and place in the light of tourism advertising as we include all the three notions in the category of nowadays important social phenomena. At the same time, the media appears in our debate as a second layer of space that positions potential hosts and potentials tourists in a different type of relation and perception of space and place. Yet, we are mainly preoccupied by the discursive aspect of space-place couple within virtual touristic experience, considered as prospective reading that may generate real exchange in the destination. This will inevitably lead us to an interdisciplinary research as we aim at balancing our study between cultural anthropology and socio-semiotics.
\end{abstract}

\section{Introduction}

The virtualisation of touristic places is no longer a new issue of debate among international scholars, as Internet plays a major role within the 'industry' of information, as well as within marketing mass-effects. In this respect, Internet became even a highly appreciated study object in the theory of enhancement. Regarded as an artificial prolongation of human's mind and body, Internet is considered to enhance at a cognitive level. Yet, remaining partly tributary to consumption, it transfers thus its functions to a more primitive level (see Maslow's pyramid).

In the case of tourism, Internet plays the mere basic, yet virtual role of a vehicle, enhancing the individual who becomes capable of starting a prospecting travelling. This type of space is known in the literature as cyberspace and defines all the atoms and their connections specific to this virtual reality.

Our aim in this paper is to demonstrate to what extent does tourism advertising produce as a cyberspace itself or to what extent it can be reconsidered within the notion of non-place, as a consequent manifestation of cyberspace.

Situated at the crossroads of cultural anthropology and social semiotics, our study prompts tourism advertising as a reconsideration of spatial discourse. As our concern targets both a review of the conceptual level (place/non-place, non-place within non-place) and the social one (Internet), this analysis is highly interdisciplinary. This lead us to one research methodology that we find most proper for cases alike: Discourse Analysis and corpus selection (see the study case).

Even though the core notion for our demonstration, non-place, is defined in nexus to semiotic understanding, as a conglomerate of (non)significations, this aspect is, yet, determined by social shifts that globalization produces at all levels. Thus, at this point, the semiotic issue dissolves in order to observe social and anthropological aspects of tourism advertising, including also ideas from consumerist studies. As this is eventually one of the principle character's of social semiotics, as T. van Leeuwen asserts: "Social semiotics is not 'pure' theory, not a self-contained field. It only comes into its own when it is applied to specific instances and specific problems, and it always requires immersing oneself not just in semiotic concepts and methods as such but also in some other field" (Leeuwen, 2005, p. 13).

*Email address:anna_c00@yahoo.com. 
Ana Crăciunescu

Starting from referential linguists such as F. de Saussure, this qualitative research demarche is sustained by scholars such as Lefebvre or de Certeau, who seize the aspects of space signification without being committed to strict boundaries of semiotics. Eventually, M. Augé completes the conceptual frame from a recent perspective on the postmodern society, leading us to its consequences at a social and cultural level that T. van Leeuwen and A. Appadurai also touch upon.

\section{Tourism advertising and space practice}

We assert that tourism advertising stands for a prospective reading ${ }^{1}$ (Crăciunescu, 2015) that the consumer/the potential tourist realizes in order to develop a consuming behaviour, after a decisional and motivational process. As a matter of fact, in our opinion, tourism advertising represents, by far, an opened window of significations towards the world, that once deciphered by the amateur semiotician (the public), constitutes a mere chance of option, a 'prospection' of the market. Therefore, the postmodern empire of choice, not only responds to desire, but also reigns successfully in a capitalist society as a landmark conferring, to a certain extent, a major alibi to advertising industry.

Lately, cyberspace incorporates print and audio-visual advertising, as well as specific social media and online advertising. Yet, firstly, in order to define cyberspace, we should analyze the significations of the term space, that appears among scholars such as de Certeau, Lefebvre and Augé in contrast or in the prolongation of the term place. Thus, in de Certeau's opinion, "a place (lieu) is the order (of whatever kind) in accord with which elements are distributed in relationships of coexistence [...] A place is thus an instantaneous configuration of positions. It implies an indication of stability" (de Certeau, 1984, p. 117). In the same author's words, the space "is composed of intersections of mobile elements. It is in a sense actuated by the ensemble of movements deployed within it" (ibid.). Eventually, appropriating place to space, de Certeau concludes that "the space could be to place what the word becomes when it is spoken" and that "space is a practised place" (ibid.). Concerning our object of study, de Certeau brings light to our demonstration, as he asserts that:

[...] an act of reading is the space produced by the practice of a particular place: a written text, i.e., a place constituted by a system of signs. (de Certeau, 1984, p. 117)

Lefebvre (1991) also realizes that "terms of everyday manner serve to distinguish [...] particular spaces" (p. 16). Furthermore, he also involves the discursive and linguistic aspects that might lead to the idea that "the result of our thinking would be the construction of a 'system of space" (ibid.). Eventually, Lefebvre touches upon the same issue as de Certeau, in the case of social space, asking rhetorically whether it must be formulated, accompanied or preconditioned by language (cf. ibid.), or, as we would say, in saussurian terms, whether social space is linguistically articulated.

In a consumerist view, Augé (1995) criticizes the over saturation of the term 'space' in the case of (popular) brands and exhibition places destined to be consumed, i.e.: "Espace Cardin", "Espace Yves Rochers", "Renault Espace” etc. (p. 83):

The craze for the word 'space' [...] expresses not only the themes that haunt the contemporary era (advertising, image, leisure, freedom, travel) but also the abstraction that corrodes and threatens them, as if the consumers of contemporary space were invited first and foremost to treat themselves to words. (Augé, 1995, p. 83)

\footnotetext{
${ }^{1}$ A syntagm that we have coined in order make less difficult to the great public the scientific language depicting a process of de-codification and choice. Briefly, it resumes the relation between the message contained by the promotional image as a whole (text, image) and the consumer reading, almost as a postmodernist cultural gesture. A process of semiosis, the prospective reading involves thus (non)conscious semiotic understanding and practice (and therefore, cultural), yet serving to enrich as well the economic lexicon, as advertising remains highly imbued in issues concerning marketing.
} 
The understanding of space through language, or the dichotomy space/place as language/speaking, that we found at all three authors, stresses on the idea of space organized as a place discourse. In the case of tourism, space may be a projected image as the result of a pre-packaged socially organized discourse within the virtual, that is, within cyberspace. On one hand, we believe that "imagination plays an important role as it triggers on our need for the virtual (or fantasia in a first phase) and is responsible for the stimulation of the travelling wish. Cyberspace speculates escapism as the major need for mind-voyaging and virtual experiencing" (Crăciunescu, 2014, p. 40). On the other hand, "the traveller's space may thus be the archetype of non-place" (Augé, 1995, p. 86).

Non-place as opposed to place defines properly an articulated space such as tourism advertising manifesting as and within cyberspace. Even though non-place is viewed as a place emptied of significations, M. Augé revaluates its meanings and roles within the consumerist society. It is a natural dimension that appears as a reaction to over-articulated place. In this respect, we may say that non-place frames itself within the features of non-discourse as opposed to discourse. Image replaces the verbal, and, thus, dissolves meaning through flows of un-articulated messages that cross the boundaries of the linguistic and therefore, of space. In comparing the abundance of information passing through flows of images to the contemporary motion of people, A. Appadurai asserts that:

As with mediation, so with motion. The story of mass migration (voluntary and forced) is hardly a new feature of human history. But when it is juxtaposed with the rapid flow of mass-mediated images, scripts, and sensations, we have a new order of instability in the production of modern subjectivities. (Appadurai, 1996, p. 4)

These 'modern subjectivities' are re-dimensioned through the tourist gaze (Urry, 2011), that more and more recently transforms, in our case, into a gaze that can uncannily reverse at any moment of the articulation within the space of the touristic destination. Gender or ethnic issues that trigger the reversed roles of the panoptic gaze, emerge as the production of power portrays the new figures of modern subjectivities. The Other represents still an issue of great impact in tourism studies and new possibilities of travelling are gazed upon through the lens of media. Yet an anti-globalization tool, otherness as tourism production in terms of favourite exotic touristic destinations may also lead to uniformity. Scholars evoke cultural imperialism through globalization and homogenisation (Machin \& Leeuwen, 2007, p. 23). This means that both the articulation and non-articulation of space within media, and thus within the virtual space (i.e. Internet) is the very form of the risk that the place as the authentic takes to differentiate, both culturally and promotionally.

Still, the 'modern subjectivities' are following or rather making the trends of tourism as experience, be it exotic or unique, thus image and imagination as non-articulating factors play an important role in promoting touristic destinations. Not only that cyberspaces embrace (non)articulated places in a dialectics of the virtual, but they also expresses the artistic dimensions of the non-place, as a zero degree of the cultural and the symbolic, in the new social structure and understanding of space practising.

\section{Switzerland video commercial: a double-layered example of (non)place virtual- ization}

An invitation to Vrin is launched in the jammed Central Station of Zürich directly from the destination source via cyberspace practice. The outdoor display becomes suddenly alive as Internet connects the host from Vrin to the passers-by in the station. Thus, Internet brings together the host and the potential tourists in a virtual experience of prospective reading prolonged beyond a second screen, that of media or the commercial itself. The tourist gaze as a spectator of this well-marketed message seizes two layers of the virtual, as he/she embraces both the reality of the commercial's space (the space of Vrin and the space of the Central Station) and the reality of the cyberspace that mediatises the commercial (the space of the $\mathrm{ad})$. 
We are exhibiting below some relevant captures of this situation of a double-layered (non)place virtualization:
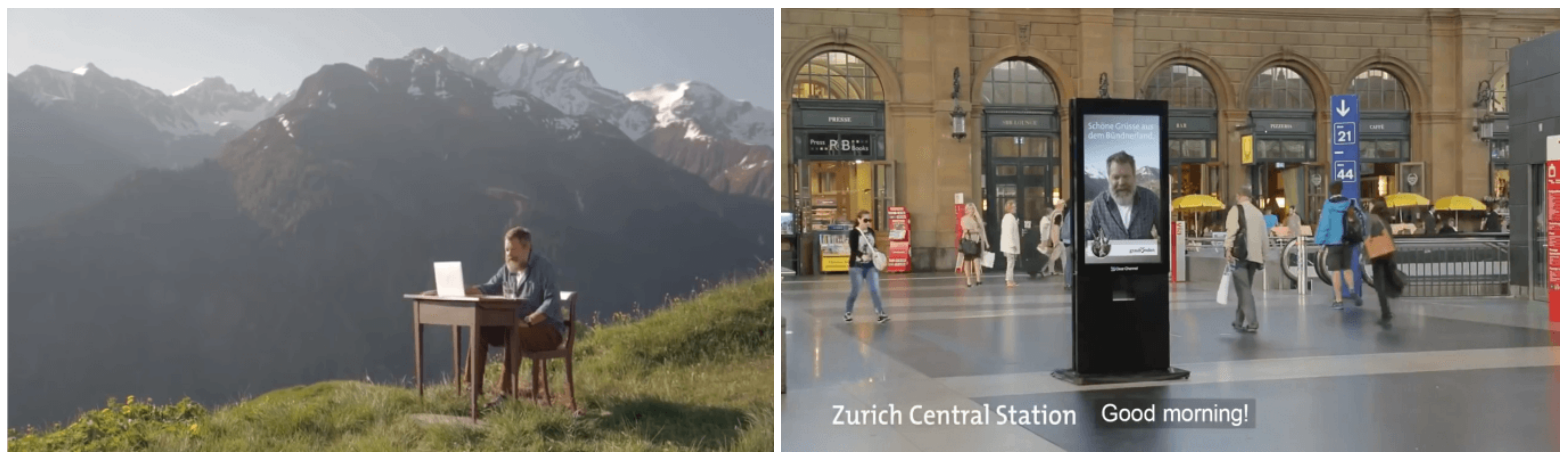

Figure 1: Screenshots of video commercial Switzerland, 2015 [online]

The direct interaction between hosts and tourists is a clear action of de-territorializing space, whilst boundaries of place are erased. Yet, the most relevant sign of this limitless and simultaneous articulation of two different spaces is the image of the arriving tourists prompted on the screen and re-projected thus in the place they left earlier. In M. Augés terms, this mediated image is a specific example of non-place, that is, of a space experience that projects image from place (the Central Station) to non-place (the image on the outdoor display: the touristic destination). Eventually, the entire commercial represents the non-place, whilst the environment of the potential tourist is the place. In this logic, we obtain different degrees of place and of non-place. Yet, in this context, non-place doesn't follow the idea of an emptied space of significations, but rather of a cyberspace, of a virtual space re-projecting place into imagined realities.
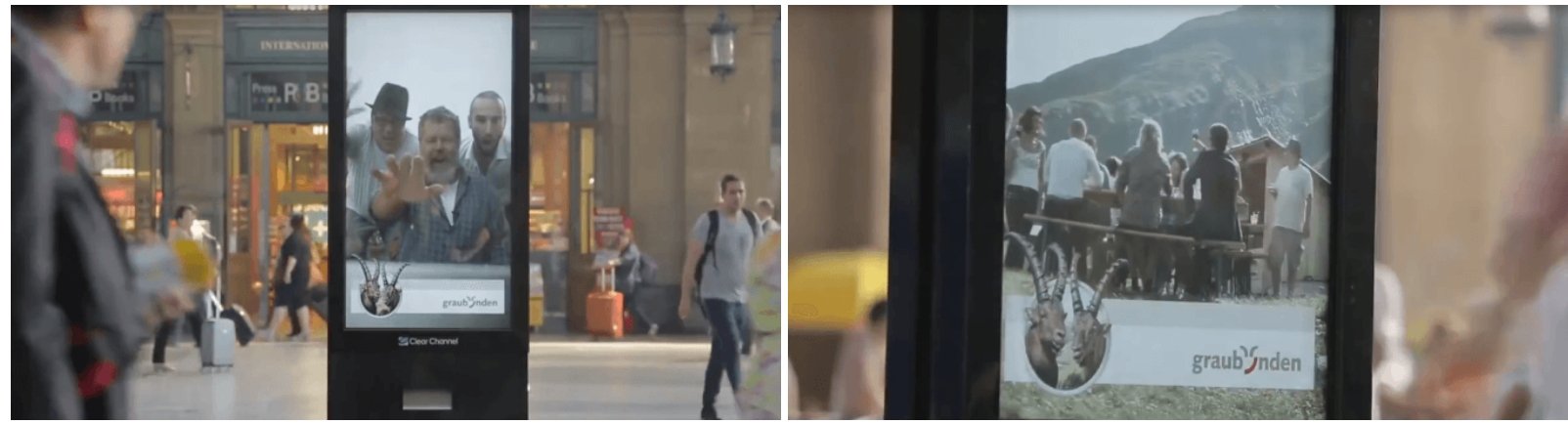

Figure 2: Non-place within non-place (Switzerland, 2015) [online]

\section{Conclusions}

As we could see in our study case, tourism advertising is not only an eloquent example of recent cyberspace practice and discourse, but also an example of non-place within non-place. Tourism advertising might be considered a virtual (non) articulated language of space that incorporates and speculates place at the utmost, in comparison to any other product. Not only that touristic destinations reveal themselves in promotional discourse within cyberspace at the distance of a click, but they can also constitute virtual experiences of prospective reading that may lead to specific consumerist behaviour. In this light, we are tempted to envisage that tourism advertising could also become a great virtual patrimony of authentic places, translated in the language of non-place differentiation. 


\section{Bibliography}

Appadurai, A. (1996). Modernity at large. Cultural Dimensions of Globalization, University of Minnesota Press. Augé, M. (1995). Non-places. Introduction to an Anthropology of Supermodernity, Verso, London - New York. de Certeau, M. (1984). The Practice of Everyday Life, University of California Press.

Crăciunescu, A. (2014). (Re)branding cities. The culture of consuming places and virtual reiterations of space in promotional touristic websites, in "Anadiss", no. 18, p. 37-53.

Crăciunescu, A. (2015). O reinterpretare a icono-textului. Noi provocări ale publicității audio-video din turism, in Grădinaru, C. (ed.), From Manuscript to E-book, Editura Universității „Al. I. Cuza”, Iași, p. 331-339.

Leeuwen, T. (2005). Introducing Social Semiotics, Routledge.

Lefebvre, H. (1991). The Production of Space, excerpts, Blackwell Publishing.

Machin, D. \& Leeuwen, T. (2007). Global Media Discourse. A Critical Introduction, Routledge.

Switzerland, 2015 = Switzerland video commercial, 2015, [online] (accessed on May 12, 2016).

Urry, J. (2011). The Tourist Gaze, Sage Publications Ltd. 